\title{
Zirconyl (IV) Nitrate as Efficient and Reusable Solid Lewis Acid Catalyst for the Synthesis of Benzimidazole Derivatives
}

\author{
Pratapsinha B. Gorepatil, Yogesh D. Mane, and Vilas S. Ingle \\ Department of Chemistry, Research Centre, S. C. S. College, Omerga, Osmanabad 413 606, India \\ Correspondence should be addressed to Pratapsinha B. Gorepatil; gorepatilpratap1986@gmail.com \\ and Vilas S. Ingle; inglevilas71@yahoo.in
}

Received 27 April 2013; Accepted 24 May 2013

Academic Editor: Stojan Stavber

Copyright (C) 2013 Pratapsinha B. Gorepatil et al. This is an open access article distributed under the Creative Commons Attribution License, which permits unrestricted use, distribution, and reproduction in any medium, provided the original work is properly cited.

The present paper introduces a simple and efficient method for the synthesis of substituted benzimidazoles by heterocyclization of different $o$-phenylenediamines and substituted aromatic carboxylic acid/aldehyde in the presence of zirconyl nitrate as catalyst in ethanol under reflux, which produced excellent yield of corresponding benzimidazoles in a short reaction time with reusability of catalyst.

\section{Introduction}

Heteroaromatic compounds have awestruck significant attention in the design of biologically active molecules and advanced organic materials $[1,2]$. Because of their pharmaceutical and biological significance, nitrogen-containing heterocyclic compounds have attracted considerable attention as an important class of organic molecules. In the continuation of our search for efficient synthetic methodologies for biologically important heterocyclic compounds, benzimidazoles have been chosen as target molecules; benzimidazole derivatives have several medicinal uses, such as antivirals, anticancer, antihypertensive, antihistamines, antiparasitics, and antiulcer [3-8].

Diverse synthetic efforts for benzimidazoles have been reported, with the most common method being the heterocyclization of $o$-phenylenediamine and carboxylic acids [9, 10], aldehydes [11, 12], alcohols [13]; and nitriles [14, 15] which usually require strong acid, high temperature, and sometimes photoirradiation conditions, precious metal salts [16], molecular oxygen $[17,18]$; or 2,3-dichloro-5,6-dicyano-1,4-benzoquinone as oxidant [19]. Recently, a variety of catalysts such as homogeneous Lewis acids [20], pyridinium- $p$-toluenesulfonate [20], ultrasonic [21], $\mathrm{I}_{2} / \mathrm{KI} / \mathrm{K}_{2} \mathrm{CO}_{3} / \mathrm{H}_{2} \mathrm{O}$ [22], ionic liquids [23], (bromodimethyl) sulfonium bromide [24], and polyaniline-sulfate [25] and a tandem oxidation process [26] have been used for the synthesis of benzimidazole derivatives.
Lewis acid catalyst has attracted considerable attention in heterogeneous catalysis [27]. Although various kinds of Lewis acids have been developed, most of them are used only under strictly anhydrous conditions, in excess, and with hazardous organic solvents which are not environment friendly. The presence of even a small amount of water stops the reactions; and most Lewis acids immediately react with water rather than substrates [28].

In this context, in the present study, we report here the use of zirconyl nitrate as eco-friendly water-soluble Lewis acid catalyst for the synthesis of substituted benzimidazole. In recent years, $\mathrm{Zr}(\mathrm{IV})$ compounds have gained special attention as catalysts in organic synthesis, and some of these are stable in aqueous media [29-31]. In the continuation of our interest in synthesis of nitrogen-containing heterocyclic compounds [32], herein wefoundedthe application of $\mathrm{ZrO}\left(\mathrm{NO}_{3}\right)_{2}$ as a Lewis acid catalyst for the synthesis of substituted benzimidazoles viathe condensation reaction between $o$-phenylenediamine and aldehyde, carboxylic acid derivatives (Scheme 1).

\section{Experimental Section}

All chemicals and reagents were purchased from commercial suppliers and used without further purification. Column chromatography was carried out with silica gel (200300 mesh) eluting with ethyl acetate and petroleum ether. 


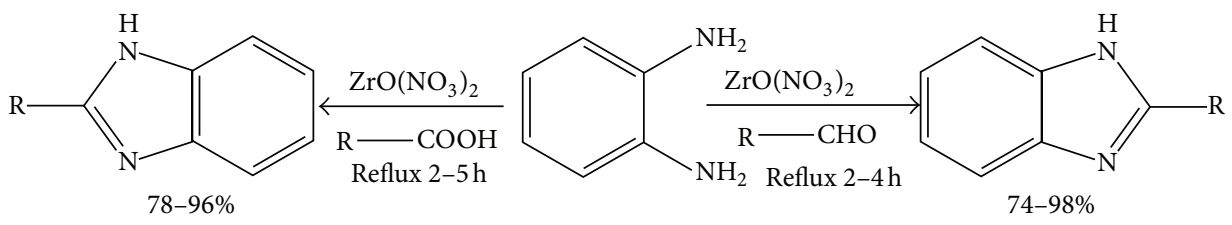

SCHEME 1: Zirconyl nitrate-catalyzed synthesis of substituted benzimidazoles.

Thin layer chromatography was carried out using Merck silica gel GF254 plates. All products were characterized by NMR. ${ }^{1} \mathrm{H} \mathrm{NMR}$ spectra were recorded at $400 \mathrm{MHz}$, and ${ }^{13} \mathrm{C} \mathrm{NMR}$ spectra were recorded at $100 \mathrm{MHz}$ with $\mathrm{CDCl}_{3}$ or DMSO- $d_{6}$ as solvent. Chemical shifts are reported in parts per million (ppm) downfield from TMS with the solvent resonance as the internal standard. Coupling constants $(J)$ are reported in $\mathrm{Hz}$ and refer to apparent peak multiplications. HRMS was recorded on an ESI source.

\section{A General Procedure for Synthesis of Substituted Benzimidazoles}

$0.5 \%$ (weight) of zirconyl nitrate was added to a solution of aldehyde/carboxylic acid $(1 \mathrm{mmol})$ and $o$-phenylenediamine $(1 \mathrm{mmol})$ in ethanol $(10 \mathrm{~mL})$. The reaction mixture was stirred under reflux for $2-6 \mathrm{~h}$. The progress of reaction was monitored by TLC. After the completion of the reaction, the reaction mixture was cooled to room temperature, $20 \mathrm{~mL}$ of ethanol was added, and resulting solution was filtered to remove the catalyst. The solvent was removed under reduced pressure by distillation, and residue was purified by column chromatography on silica gel using $n$-hexane-ethyl acetate or ethyl acetate-petroleum ether as an elutingagent The structures of the benzimidazole were characterized by ${ }^{1} \mathrm{H} \mathrm{NMR},{ }^{13} \mathrm{C} \mathrm{NMR}$, FTIR, and HRMS and were mostly known compounds.

Note. Excellent yield was obtained when 1\% (weight) of zirconyl nitrate was used with carboxylic acids.

Characterization of selected compounds is as follows.

3.1. 2-Methyl-1H-benzimidazole (Table 2, Entry 1). Solid; mp $178-180^{\circ} \mathrm{C}$ (lit. ${ }^{34} \mathrm{mp} 175-176^{\circ} \mathrm{C}$ ); IR (KBr) 3860, 3735, 3601, 2815, 2310, 1700, 1513, $735 \mathrm{~cm}^{-1}$; ${ }^{1} \mathrm{H}$ NMR (DMSO- $d_{6}, 400$ $\mathrm{MHz}) \delta 9.82(\mathrm{~s}, 1 \mathrm{H}), 7.3(d, J=8.0 \mathrm{~Hz}, 2 \mathrm{H}), 7.59(\mathrm{~d}, 2 \mathrm{H}), 2.70$ $(\mathrm{s}, 3 \mathrm{H}) ;{ }^{13} \mathrm{CNMR}$ (DMSO- $\left.d_{6}, 100 \mathrm{MHz}\right) \delta 151.35,138.60$, 122.21, 114.48, 14.90. MS (EI, $m / z): 132\left[\mathrm{M}^{+}\right]$.

3.2. 2-Phenyl-1H-benzimidazole (Table 2, Entry 2). Solid; mp

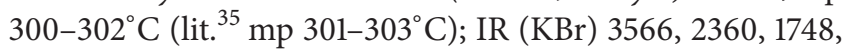
$1716,1698,1683,1652,1616 \mathrm{~cm}^{-1} ;{ }^{1} \mathrm{H}$ NMR (DMSO- $d_{6}, 400$ $\mathrm{MHz}) \delta 12.92(\mathrm{~s}, 1 \mathrm{H}), 8.19(d, J=8.0 \mathrm{~Hz}, 2 \mathrm{H}), 7.61-7.55(\mathrm{~m}$, $4 \mathrm{H}), 7.52-7.48(\mathrm{~m}, 1 \mathrm{H}), 7.23-7.19(\mathrm{~m}, 2 \mathrm{H}) ;{ }^{13} \mathrm{C}$ NMR (DMSO$\left.d_{6}, 100 \mathrm{MHz}\right) \delta 151.7,144.3,135.5,130.7,130.3,129.4,126.9$, 123.0, 122.1, 119.4, 111.8. MS (EI, $m / z): 194\left[\mathrm{M}^{+}\right]$.

3.3. 2-(4-Nitrophenyl)-1H-benzimidazole (Table 2, Entry 3). Solid; mp 324-326 C (lit. ${ }^{35} \mathrm{mp} 326-327^{\circ} \mathrm{C}$ ); IR (KBr) 3740,
$3644,3058,1766,1691,1658,1649,1597,1563,1536,1493$, $1415,722,695 \mathrm{~cm}^{-1} ;{ }^{1} \mathrm{H}$ NMR (DMSO- $\left.d_{6}, 400 \mathrm{MHz}\right) \delta 13.30$ (s, 1H), $8.42(\mathrm{~s}, 4 \mathrm{H}), 7.74(\mathrm{~s}, 1 \mathrm{H}), 7.60(\mathrm{~s}, 1 \mathrm{H}), 7.28(\mathrm{~s}, 2 \mathrm{H})$. ${ }^{13} \mathrm{CNMR}\left(\mathrm{DMSO}-d_{6}, 100 \mathrm{MHz}\right) \delta 162.7,157.8,149.4,148.2$, $136.5,127.8,127.4,124.7,123.3,119.8,112.4$. MS (EI, $m / z): 239$ $\left[\mathrm{M}^{+}\right]$.

3.4. 5-Methyl-2-phenyl-1H-benzimidazole (Table 2, Entry 7). Solid; mp $245-247^{\circ} \mathrm{C}$ (lit. ${ }^{36} \mathrm{mp} 243-244^{\circ} \mathrm{C}$ ); IR (KBr) 3109, 1511, 1463, 1354, 1176, 739, 701, $657 \mathrm{~cm}^{-1} ;{ }^{1} \mathrm{H}$ NMR $\left(\mathrm{CDCl}_{3}\right.$, $400 \mathrm{MHz}) \delta 8.54(\mathrm{~s}, 1 \mathrm{H}), 8.12-8.11(\mathrm{~m}, 2 \mathrm{H}), 7.53(d, J=5.5 \mathrm{~Hz}$, $1 \mathrm{H}), 7.40(\mathrm{~m}, 2 \mathrm{H}), 7.28(\mathrm{~s}, 2 \mathrm{H}), 7.08(d, J=5.5 \mathrm{~Hz}, 1 \mathrm{H}), 2.45(\mathrm{~s}$, $3 \mathrm{H}) ;{ }^{13} \mathrm{C}$ NMR (DMSO, $\left.100 \mathrm{MHz}\right) \delta 151.3,131.8,130.8,130.1$, $129.6,129.4,129.2,126.8,126.6,126.4,124.0,21.8$. MS (EI, $m / z)$ : $208\left[\mathrm{M}^{+}\right]$.

3.5. 2-(p-Tolyl)-1H-benzimidazole (Table 2, Entry 16). Solid; mp 264-266 ${ }^{\circ} \mathrm{C}$ (lit. ${ }^{35} \mathrm{mp} 263-265^{\circ} \mathrm{C}$ ); ${ }^{1} \mathrm{H}$ NMR (DMSO- $d_{6}$, $400 \mathrm{MHz}) \delta 12.83(\mathrm{~s}, 1 \mathrm{H}), 8.08(d, J=7.8 \mathrm{~Hz}, 2 \mathrm{H}), 7.59(\mathrm{~s}$, 2H), 7.37 ( $d, J=7.8 \mathrm{~Hz}, 2 \mathrm{H}), 7.21-7.19(\mathrm{~m}, 2 \mathrm{H}), 2.39$ (s, 3H); ${ }^{13} \mathrm{CNMR}\left(\mathrm{DMSO}-d_{6}, 100 \mathrm{MHz}\right) \delta 151.9,144.3,140.0,135.4$, $130.0,127.9,126.9,122.8,122.0,119.2,111.7,21.4$. MS (EI, $m / z)$ : $208\left[\mathrm{M}^{+}\right]$.

3.6. 2-(4-Methoxyphenyl)-1H-benzimidazole (Table 2, Entry 6). Solid; mp $235-237^{\circ} \mathrm{C}$ (lit. ${ }^{35} \mathrm{mp} 234-235^{\circ} \mathrm{C}$ ); ${ }^{1} \mathrm{HNMR}$ $\left(\mathrm{DMSO}-d_{6}, 400 \mathrm{MHz}\right) \delta 7.44(d, J=7.2 \mathrm{~Hz}, 1 \mathrm{H}), 7.25-7.19(\mathrm{~m}$, $2 \mathrm{H}), 7.09(d, J=8.8 \mathrm{~Hz}, 2 \mathrm{H}), 6.95(d, J=8.4 \mathrm{~Hz}, 2 \mathrm{H}), 6.85(d$, $J=8.8 \mathrm{~Hz}, 2 \mathrm{H}), 3.83(\mathrm{~s}, 3 \mathrm{H}) ;{ }^{13} \mathrm{C}$ NMR (DMSO- $\left.d_{6}, 100 \mathrm{MHz}\right)$ $\delta 160.8,153.6,143.2,136.3,129.3,127.9,122.5,119.4,114.7,114.6$, 111.5, 55.8. MS (EI, $m / z): 224\left[\mathrm{M}^{+}\right]$.

3.7. 5-Nitro-2-(4-methylphenyl)-1H-benzimidazole (Table 2, Entry 12). Solid; mp $288^{\circ} \mathrm{C}$ (lit. mp 290-292 ${ }^{\circ} \mathrm{C}$ ); IR (KBr) 3858, 3747, 3672, 3059, 2349, 1805, 1691, 1649, 1641, 1597, 1493, $1135,1025,722,695 \mathrm{~cm}^{-1}$; ${ }^{1} \mathrm{H}$ NMR (DMSO- $\left.d_{6}, 400 \mathrm{MHz}\right) \delta$ $13.50(\mathrm{~s}, 1 \mathrm{H}), 8.10(d, J=7.7 \mathrm{~Hz}, 2 \mathrm{H}), 7.95(d, J=8.9 \mathrm{~Hz}, 1 \mathrm{H})$, $7.39(d, J=7.8 \mathrm{~Hz}, 2 \mathrm{H}), 6.73(\mathrm{~s}, 1 \mathrm{H}), 6.61(d, J=8.9 \mathrm{~Hz}, 1 \mathrm{H})$, $2.39(\mathrm{~s}, 3 \mathrm{H}) ;{ }^{13} \mathrm{C}$ NMR (DMSO- $\left.d_{6}, 100 \mathrm{MHz}\right) \delta 156.2,136.1$, 130.2, 129.1, 127.4, 126.8, 119.2, 118.6, 115.1, 112.8, 112.1, 21.5; MS $(\mathrm{EI}, \mathrm{m} / z): 254\left[\mathrm{M}^{+}\right]$.

3.8. 2-(4-Chlorophenyl)-1H-benzimidazole (Table 2, Entries 4 and 15). Solid; $\mathrm{mp} 294-296^{\circ} \mathrm{C}$ (lit. ${ }^{35} \mathrm{mp} 290-292^{\circ} \mathrm{C}$ ); IR (KBr) 3606, 3001, 2818, 2310, 1700, 1513, $735 \mathrm{~cm}^{-1}$; ${ }^{1} \mathrm{H}$ NMR $\left(\mathrm{DMSO}-d_{6}, 400 \mathrm{MHz}\right) \delta 13.00(\mathrm{~s}, 1 \mathrm{H}), 8.20(d, J=8.4 \mathrm{~Hz}, 2 \mathrm{H})$, 
TABLE 1: Optimization of reaction conditions ${ }^{\mathrm{a}}$ for synthesis of substituted benzimidazoles from benzaldehyde/benzoic acid with $o$ phenylenediamine.

\begin{tabular}{|c|c|c|c|c|}
\hline \multirow{2}{*}{ Entry } & \multirow{2}{*}{ Solvents } & \multirow{2}{*}{$\begin{array}{l}\text { Catalyst conc. } \\
\text { (weight \%) }\end{array}$} & \multicolumn{2}{|c|}{ Yield $^{\mathrm{b}}(\%) /$ reaction time $(\mathrm{h})$} \\
\hline & & & Benzaldehyde & Benzoic acid \\
\hline 1 & Ethanol & No catalyst & $27 / 6$ & $45 / 14$ \\
\hline 2 & Ethanol & 0.3 & $58 / 3$ & $65 / 6$ \\
\hline 3 & Ethanol & 0.5 & $96 / 2$ & $90 / 3$ \\
\hline 4 & Ethanol & 1 & $94 / 2.5$ & $94 / 3$ \\
\hline 5 & Dioxane & 0.5 & $82 / 3$ & $75 / 4.5$ \\
\hline 6 & EtOAc & 0.5 & $85 / 3.5$ & $78 / 5$ \\
\hline 7 & DCM & 1 & $70 / 4$ & $80 / 6$ \\
\hline
\end{tabular}

${ }^{\mathrm{a}}$ Reflux the reaction mixture. ${ }^{\mathrm{b}}$ Isolated yield.

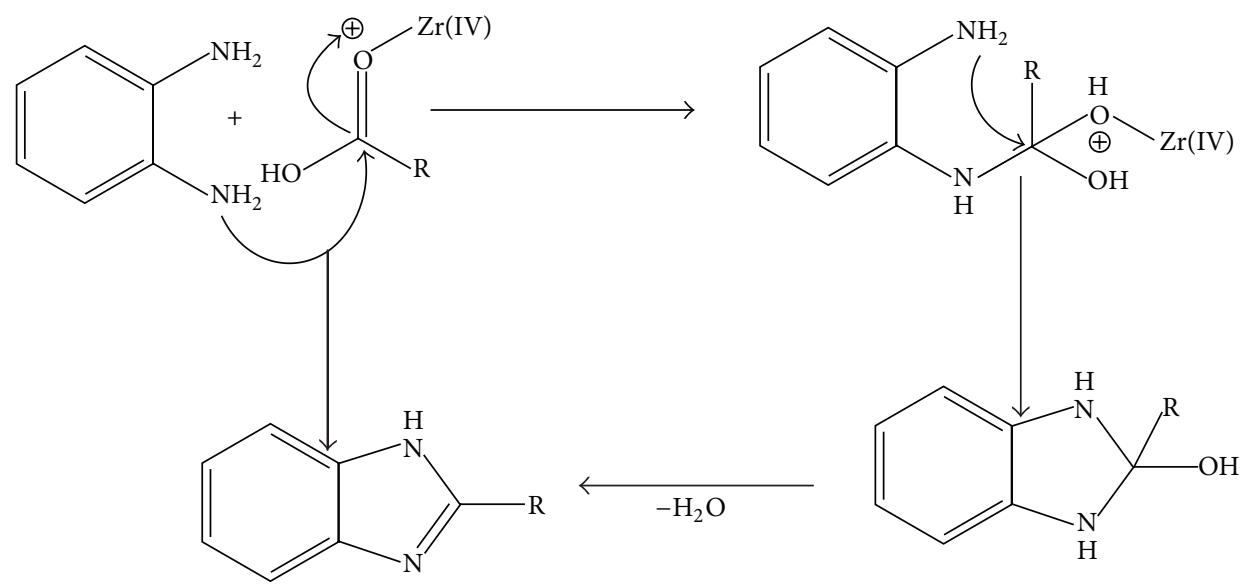

Scheme 2: Possible mechanism for the $\operatorname{Zr}(\mathrm{IV})$-catalyzed synthesis of benzimidazoles form carboxylic acids.

$7.64(d, J=8.4 \mathrm{~Hz}, 4 \mathrm{H}), 7.24-7.21(\mathrm{~m}, 2 \mathrm{H}) ;{ }^{13} \mathrm{C}$ NMR (DMSO$\left.d_{6}, 100 \mathrm{MHz}\right) \delta 150.6,144.3,135.0,134.8,129.5,128.6,128.2$, $122.9,122.5,119.4,111.9$. MS (EI, $m / z): 228\left[\mathrm{M}^{+}\right]$.

3.9. 5-Methyl-2-(4-nitrophenyl)-1H-benzimidazole (Table 2, Entries 9 and 18). Solid; $\mathrm{mp} 278-280^{\circ} \mathrm{C}$ (lit. mp $280-282^{\circ} \mathrm{C}$ ); ${ }^{1} \mathrm{H}$ NMR (DMSO- $\left.d_{6}, 400 \mathrm{MHz}\right) \delta 8.39(\mathrm{~s}, 5 \mathrm{H}), 7.54(d, J=$ $8.0 \mathrm{~Hz}, 1 \mathrm{H}), 7.43(\mathrm{~s}, 1 \mathrm{H}), 7.09(d, J=8.3 \mathrm{~Hz}, 1 \mathrm{H}), 2.44(\mathrm{~s}, 3 \mathrm{H})$; ${ }^{13}$ C NMR (DMSO- $\left.d_{6}, 100 \mathrm{MHz}\right) \delta 159.0,153.6,143.2,136.3$, $131.0,129.3,127.9,119.4,114.7,114.6,111.5,31.1$. MS (EI, $m / z)$ : $254\left[\mathrm{M}^{+}\right]$

3.10. 2-(3-Methylphenyl)-1H-benzimidazole (Table 2, Entries 5 and 19). Solid; $\mathrm{mp} 285-287^{\circ} \mathrm{C}$ (lit. mp 286-288 $\mathrm{C}$ ); ${ }^{1} \mathrm{H}$ NMR $\left(\mathrm{DMSO}-d_{6}, 400 \mathrm{MHz}\right) \delta 12.88(\mathrm{~s}, 1 \mathrm{H}), 8.03(\mathrm{~s}, 1 \mathrm{H}), 7.98(d, J$
$=7.8 \mathrm{~Hz}, 1 \mathrm{H}), 7.60(\mathrm{~s}, 2 \mathrm{H}), 7.44(t, J=7.6 \mathrm{~Hz}, 1 \mathrm{H}), 7.31(d, J=$ $7.6 \mathrm{~Hz}, 1 \mathrm{H}), 7.23-7.19(\mathrm{~m}, 2 \mathrm{H}), 2.42(\mathrm{~s}, 3 \mathrm{H}) ;{ }^{13} \mathrm{C}$ NMR (DMSO$\left.d_{6}, 100 \mathrm{MHz}\right) \delta 156.2,143.1,141.4,136.1,130.1,127.4,126.8,126.7$, 118.3, 112.8, 21.5. MS (EI, $m / z): 208\left[\mathrm{M}^{+}\right]$.

\section{Results and Discussion}

We examined the cyclocondensation of $o$-phenylenediamine with different substituted aromatic carboxylic acid/aldehydes using zirconyl nitrate/Zr(IV) as a Lewis acid catalyst for the synthesis of substituted benzimidazoles. While establishing a new synthetic route, solvent and catalyst play an important role in organic synthesis. We studied the effect of solvent and molecular percent weight of catalyst on the synthesis of benzimidazoles using $\mathrm{ZrO}\left(\mathrm{NO}_{3}\right)_{2}$. Among various solvents, 
TABLE 2: Synthesis of substituted benzimidazoles by $\mathrm{ZrO}\left(\mathrm{NO}_{3}\right)_{2}$-catalyzed reaction between aromatic aldehydes and carboxylic acids with $o$-phenylenediamines.

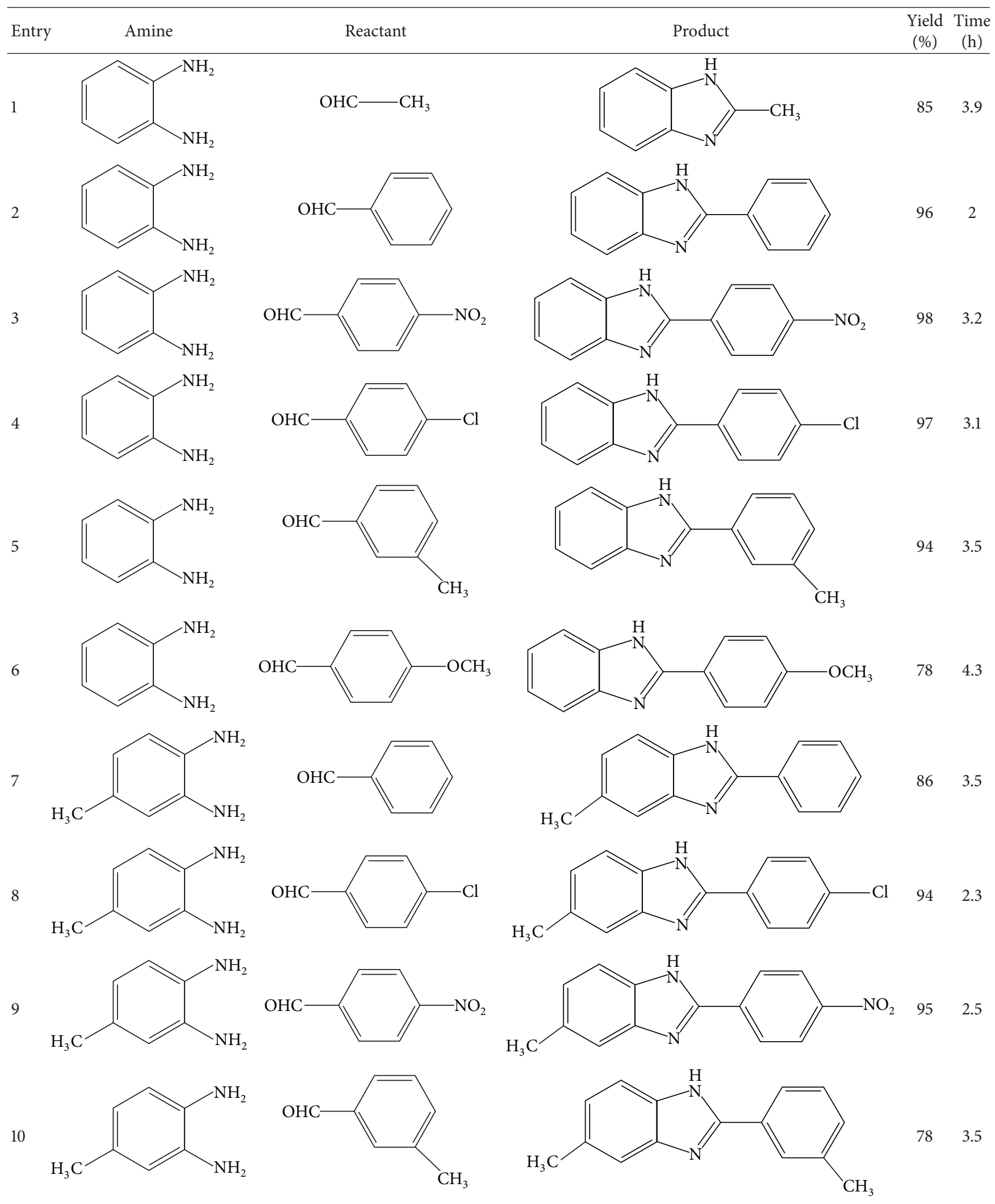


TABle 2: Continued.

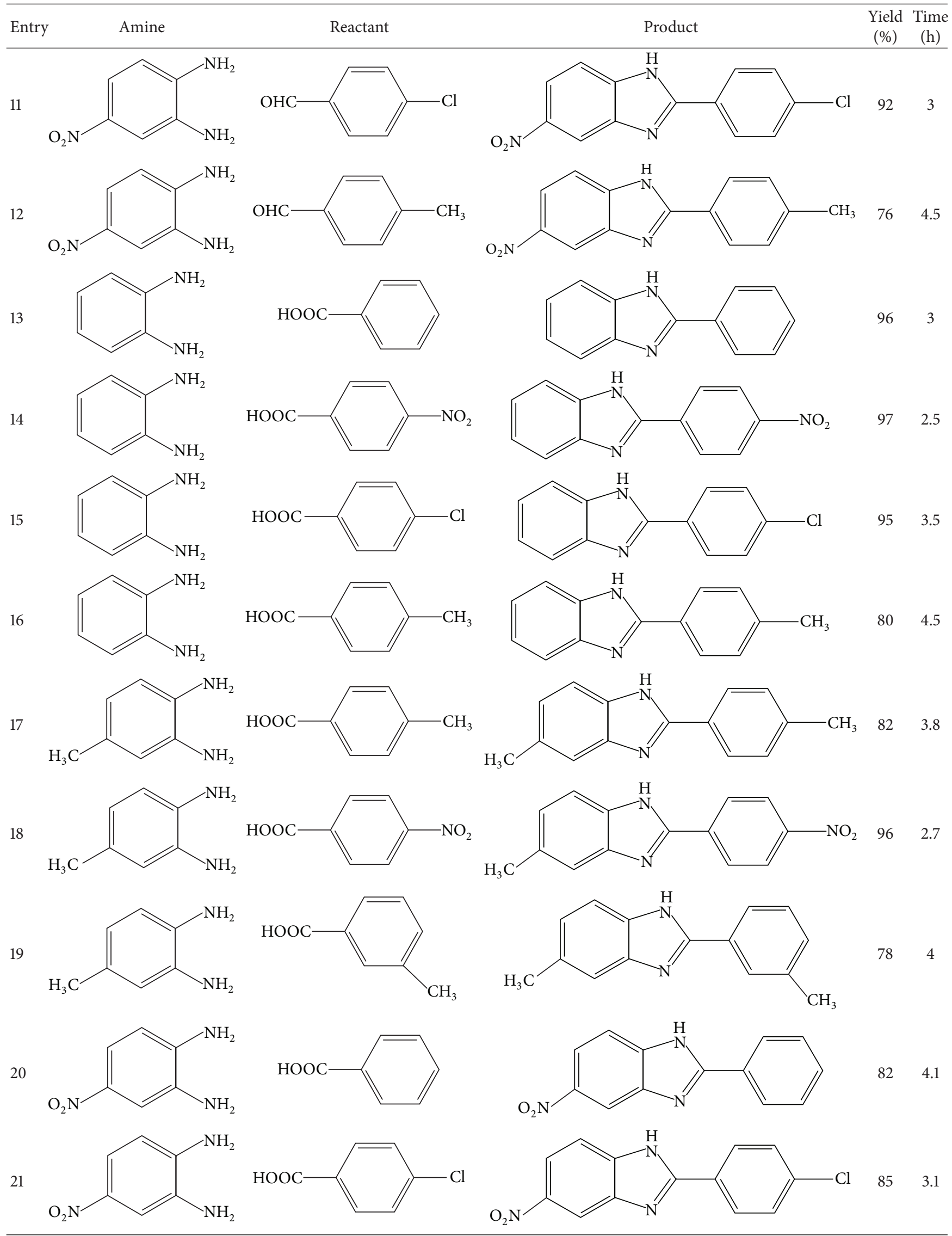


TABLe 2: Continued.

Entry Amine Reactant

${ }^{\text {a } I s o l a t e d ~ y i e l d . ~}$

TABLE 3: Catalyst reusability study for the reaction of benzaldehyde with $o$-phenylenediamine ${ }^{\text {a }}$.

\begin{tabular}{lcc}
\hline Entry & \\
\hline & 96 & 97 \\
3 & 93 & 94 \\
4 & 90 & 92 \\
98 & 91 \\
\hline
\end{tabular}

${ }^{\mathrm{a}}$ Reaction condition: benzaldehyde $(1 \mathrm{mmol}), o$-phenylenediamine $(1 \mathrm{mmol}), \mathrm{ZrO}\left(\mathrm{NO}_{3}\right)_{2}(0.5$ wt. $\%)$, ethanol, reflux. ${ }^{\mathrm{b}}$ Isolated yield.

dichloromethane, dioxane, ethyl acetate, and ethanol were used and their results are shown in Table 1.

Initially, the reaction between o-phenylenediamine ( 1 $\mathrm{mmol})$ and benzaldehyde $(1 \mathrm{mmol})$ was selected for the synthesis of benzimidazoles as a model reaction for optimization. It was found that ethanol gave the highest yield (96\%) when using $0.5 \%$ zirconyl nitrate for $2 \mathrm{~h}$, compared to other solvents and different molecular percent weight of catalyst used in the reaction (Table 1 , entry 3 ).

In the continuation of our scheme, to search for better alternative route by using the same catalyst, we also carried out the reaction between substituted benzoic acids with $o$ phenylenediamine. To optimize this reaction we used benzoic acid ( $1 \mathrm{mmol})$ as a model; it also produced good yield of 2phenyl-1H-benzimidazole in ethanol, but excellent yield was obtained when $1 \%$ of zirconyl nitrate was used with carboxylic acid (Table 1, entry 4). As per a possible mechanism the reaction proceeds via the activation of carboxylic acid by $\mathrm{Zr}(\mathrm{IV})$ which is shown in Scheme 2.

After the optimization of the reaction condition, we extended the study with different $o$-phenylenediamine against different aromatic and aliphatic aldehydes, aromatic carboxylic acids. In general, most of the reactions proceeded very smoothly to give corresponding substituted benzimidazoles in moderate to excellent yields, and the results are summarized in Table 2 (entries 1-22).

Then, we examined the general applicability of this synthetic route by using a variety of substituted benzaldehydes and carboxylic acids for the study of electronic factors. It is clearly seen from the Table 2 that the electron-deficient analogues give good yield in a short reaction time as compared to electron-rich ones. Another advantage of the present methodology is the reusability of the catalyst. After the completion of the reaction, the catalyst is removed by the simple filtration and it is treated with dichloromethane. The catalyst is dried at $80^{\circ} \mathrm{C}$ for $2 \mathrm{~h}$ and can be reused for another reaction. The recycled catalyst is used for four consecutive reactions without any appreciable change in its catalytic activity; the results are shown in Table 3.

\section{Conclusion}

In conclusion, a facile methodology for synthesis of substituted benzimidazoles in good to excellent yield is provided by zirconyl-nitrate-catalyzed condensation reaction of substituted $o$-phenylenediamines and aldehyde/carboxylic acid. The zirconyl-nitrate-catalyzed system reduced the reaction time and increased the yields. The environmental compatibility, excellent reusability of the catalyst, and ease for isolation of product are among the other added advantages that made this approach a good alternative way for the synthesis of benzimidazole derivatives.

\section{Acknowledgment}

Pratapsinha B. Gorepatil is thankful to the CSIR, New Delhi, for Junior Research Fellowship (JRF).

\section{References}

[1] M. S. M. Ahmed, K. Kobayashi, and A. Mori, "One-pot construction of pyrazoles and isoxazoles with palladium-catalyzed four-component coupling," Organic Letters, vol. 7, no. 20, pp. 4487-4489, 2005.

[2] M. Kidwai, R. Poddar, S. Diwaniyan, and R. C. Kuhad, "Laccase from basidiomycetous fungus catalyzes the synthesis of substituted 5-deaza-10-oxaflavins via a domino reaction," Advanced Synthesis and Catalysis, vol. 351, no. 4, pp. 589-595, 2009. 
[3] D. A. Horton, G. T. Bourne, and M. L. Smythe, "The combinatorial synthesis of bicyclic privileged structures or privileged substructures," Chemical Reviews, vol. 103, no. 3, pp. 893-930, 2003.

[4] M. Alamgir, D. S. Black, and N. Kumar, "Synthesis, reactivity and biological activity of benzimidazoles," Topics in Heterocyclic Chemistry, vol. 9, pp. 87-118, 2007.

[5] J. M. Woynarowski, M. McHugh, R. D. Sigmund, and T. A. Beerman, "Modulation of topoisomerase II catalytic activity by DNA minor groove binding agents distamycin, Hoechst 33258, and 4',6-diamidine-2-phenylindole," Molecular Pharmacology, vol. 35, no. 2, pp. 177-182, 1989.

[6] A. Y. Chen, C. Yu, B. Gatto, and L. F. Liu, "DNA minor groovebinding ligands: a different class of mammalian DNA topoisomerase I inhibitors," Proceedings of the National Academy of Sciences of the United States of America, vol. 90, no. 17, pp. 81318135, 1993.

[7] J. S. Kim, B. Gatto, C. Yu, A. Liu, L. F. Liu, and E. J. LaVoie, "Substituted 2,5'-Bi-1H-benzimidazoles: topoisoraerase I inhibition and cytotoxicity," Journal of Medicinal Chemistry, vol. 39, no. 4, pp. 992-998, 1996.

[8] T. Roth, M. L. Morningstar, P. L. Boyer, S. H. Hughes, R. W. Buckheit Jr., and C. J. Michejda, "Synthesis and biological activity of novel nonnucleoside inhibitors of HIV-1 reverse transcriptase. 2-aryl-substituted benzimidazoles," Journal of Medicinal Chemistry, vol. 40, no. 26, pp. 4199-4207, 1997.

[9] P. N. Preston, "Synthesis, reactions, and spectroscopic properties of benzimidazoles," Chemical Reviews, vol. 74, no. 3, pp. 279-314, 1974.

[10] K. Bahrami, M. M. Khodaei, and I. Kavianinia, "A simple and efficient one-pot synthesis of 2-substituted benzimidazoles," Synthesis, no. 4, pp. 547-550, 2007.

[11] P. L. Beaulieu, B. Haché, and E. von Moos, "A practical oxone -mediated, high-throughput, solution-phase synthesis of benzimidazoles from 1,2-phenylenediamines and aldehydes and its application to preparative scale synthesis," Synthesis, no. 11, pp. 1683-1692, 2003.

[12] Y. Shiraishi, Y. Sugano, S. Tanaka, and T. Hirai, "One-pot synthesis of benzimidazoles by simultaneous photocatalytic and catalytic reactions on $\mathrm{Pt} @ \mathrm{TiO}_{2}$ nanoparticles," Angewandte Chemie-International Edition, vol. 49, no. 9, pp. 1656-1660, 2010.

[13] J. Sluiter and J. Christoffers, "Synthesis of 1-methylbenzimidazoles from carbonitriles," Synlett, no. 1, pp. 63-66, 2009.

[14] D. W. Hein, R. J. Alheim, and J. J. Leavitt, "The use of polyphosphoric acid in the synthesis of 2-aryl- and 2-alkyl-substituted benzimidazoles, benzoxazoles and benzothiazoles," Journal of the American Chemical Society, vol. 79, no. 2, pp. 427-429, 1957.

[15] R. Trivedi, S. K. De, and R. A. Gibbs, "A convenient one-pot synthesis of 2-substituted benzimidazoles," Journal of Molecular Catalysis A, vol. 245, no. 1-2, pp. 8-11, 2006.

[16] Y.-X. Chen, L.-F. Qian, W. Zhang, and B. Han, "Efficient aerobic oxidative synthesis of 2-substituted benzoxazoles, benzothiazoles, and benzimidazoles catalyzed by 4-methoxy-TEMPO," Angewandte Chemie-International Edition, vol. 47, no. 48, pp. 9330-9333, 2008.

[17] G. A. Molander and K. Ajayi, "Oxidative condensations to form benzimidazole-substituted potassium organotrifluoroborates," Organic Letters, vol. 14, p. 4242, 2012.

[18] M. R. Grimmett, Imidazole and Benzimidazole Synthesis, Academic Press, London, UK, 1997.
[19] M. Curini, F. Epifano, F. Montanari, O. Rosati, and S. Taccone, "Ytterbium triflate promoted synthesis of benzimidazole derivatives," Synlett, no. 10, pp. 1832-1834, 2004.

[20] K. R. Hornberger, G. M. Adjabeng, H. D. Dickson, and R. G. Davis-Ward, "A mild, one-pot synthesis of disubstituted benzimidazoles from 2-nitroanilines," Tetrahedron Letters, vol. 47, no. 30, pp. 5359-5361, 2006.

[21] V. Mirkhani, M. Moghadam, S. Tangestaninejad, and H. Kargar, "Rapid and efficient synthesis of 2-imidazolines and bis-imidazolines under ultrasonic irradiation," Tetrahedron Letters, vol. 47, no. 13, pp. 2129-2132, 2006.

[22] P. Gogoi and D. Konwar, "An efficient and one-pot synthesis of imidazolines and benzimidazoles via anaerobic oxidation of carbon-nitrogen bonds in water," Tetrahedron Letters, vol. 47, no. 1, pp. 79-82, 2006.

[23] R. N. Nadaf, S. A. Siddiqui, T. Daniel, R. J. Lahoti, and K. V. Srinivasan, "Room temperature ionic liquid promoted regioselective synthesis of 2-aryl benzimidazoles, benzoxazoles and benzthiazoles under ambient conditions," Journal of Molecular Catalysis A, vol. 214, no. 1, pp. 155-160, 2004.

[24] B. Das, H. Holla, and Y. Srinivas, "Efficient (bromodimethyl) sulfonium bromide mediated synthesis of benzimidazoles," Tetrahedron Letters, vol. 48, no. 1, pp. 61-64, 2007.

[25] U. Srinivas, C. Srinivas, P. Narender, V. J. Rao, and S. Palaniappan, "Polyaniline-sulfate salt as an efficient and reusable catalyst for the synthesis of 1,5-benzodiazepines and 2-phenyl benzimidazoles," Catalysis Communications, vol. 8, no. 1, pp. 107110, 2007.

[26] C. D. Wilfred and R. J. K. Taylor, "Preparation of 2-substituted benzimidazoles and related heterocycles directly from activated alcohols using TOP methodology," Synlett, no. 9, pp. 1628-1630, 2004.

[27] A. Corma and H. García, "Lewis acids: from conventional homogeneous to green homogeneous and heterogeneous catalysis," Chemical Reviews, vol. 103, no. 11, pp. 4307-4365, 2003.

[28] S. Kobayashi and K. Manabe, "Development of novel Lewis acid catalysts for selective organic reactions in aqueous media," Accounts of Chemical Research, vol. 35, no. 4, pp. 209-217, 2002.

[29] H. Firouzabadi and M. Jafarpour, "Some applications of zirconium(IV) tetrachloride $\left(\mathrm{ZrCl}_{4}\right)$ and zirconium(IV) oxydichloride octahydrate $\left(\mathrm{ZrOCl}_{2} \cdot 8 \mathrm{H}_{2} \mathrm{O}\right)$ as catalysts or reagents in organic synthesis," Journal of the Iranian Chemical Society, vol. 5, no. 2, pp. 159-183, 2008.

[30] F. K. Behbahani, P. Ziaei, Z. Fakhroueian, and N. Doragi, "An efficient synthesis of 2-arylbenzimidazoles from $o$-phenylenediamines and arylaldehydes catalyzed by $\mathrm{Fe} / \mathrm{CeO}_{2}-\mathrm{ZrO}_{2}$ nano fine particles," Monatshefte für Chemie, vol. 142, no. 9, pp. 901-906, 2011.

[31] R. V. Shingalapur and K. M. Hosamani, "An efficient and ecofriendly tungstate promoted zirconia $\left(\mathrm{WO}_{x} / \mathrm{ZrO}_{2}\right)$ solid acid catalyst for the synthesis of 2-aryl benzimidazoles," Catalysis Letters, vol. 137, no. 1-2, pp. 63-68, 2010.

[32] P. B. Gorepatil, Y. D. Mane, V. S. Surywanshi, V. S. Shinde, and V. S. Ingle, "One pot synthesis of antimicrobial active new 2-benzimidazolesulfonamide derivatives from 2-mercaptobenzimidazole," Journal Current Chemical and Pharmaceutical Sciences, vol. 2, no. 4, p. 367, 2012. 

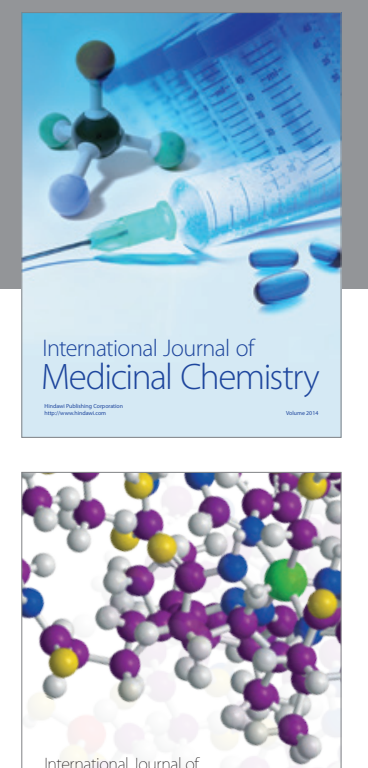

\section{Carbohydrate} Chemistry

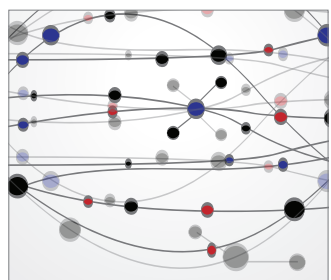

The Scientific World Journal
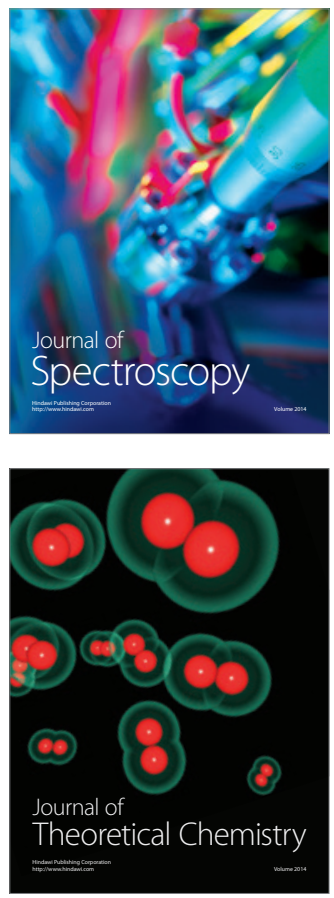
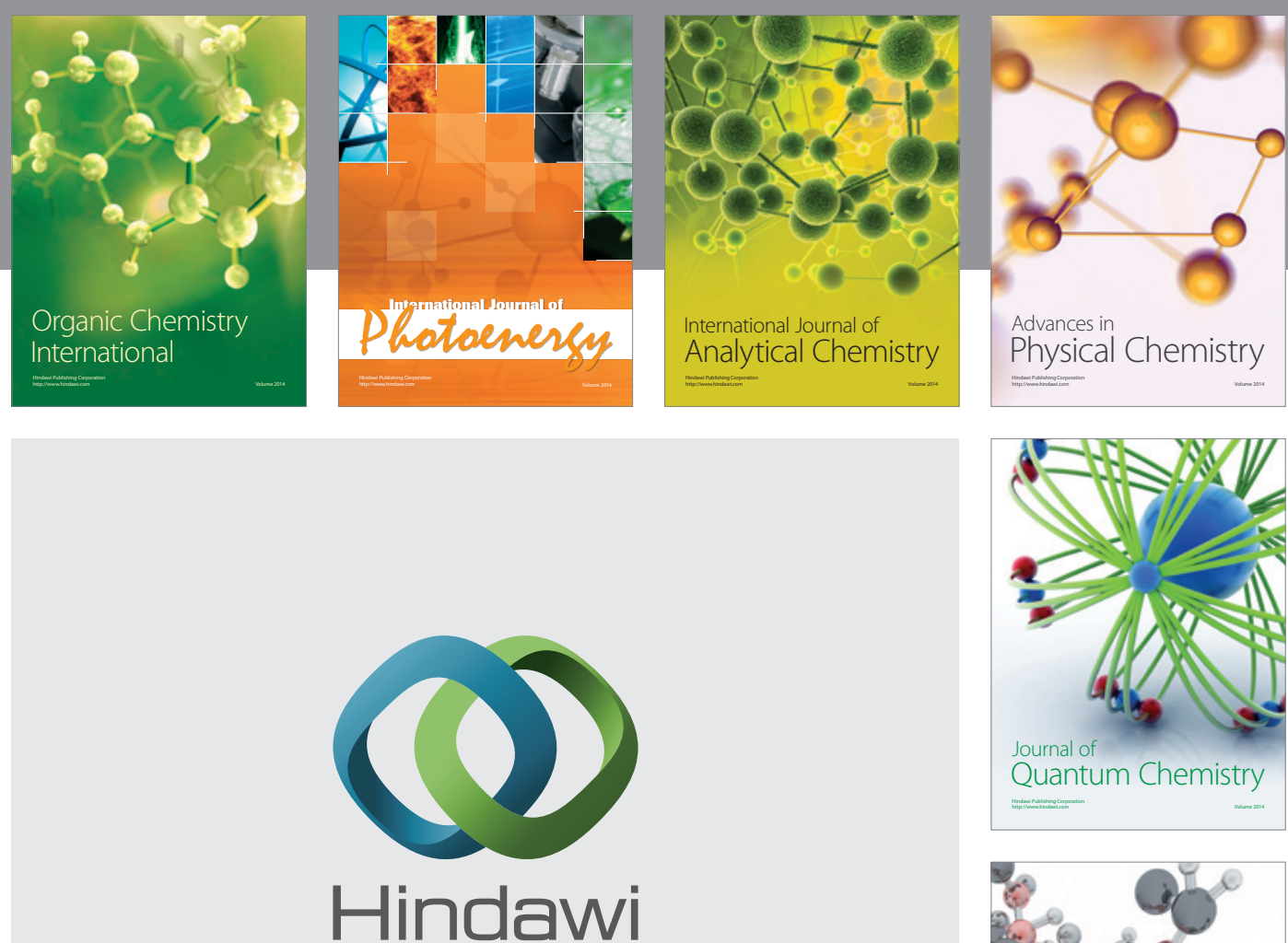

Submit your manuscripts at

http://www.hindawi.com

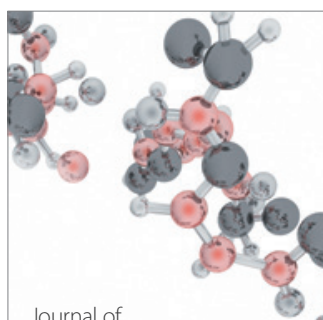

Analytical Methods

in Chemistry

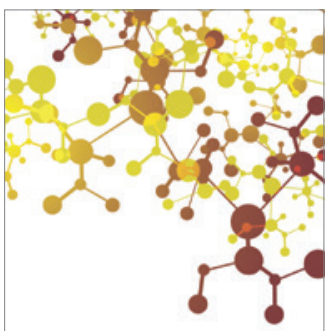

Journal of

Applied Chemistry

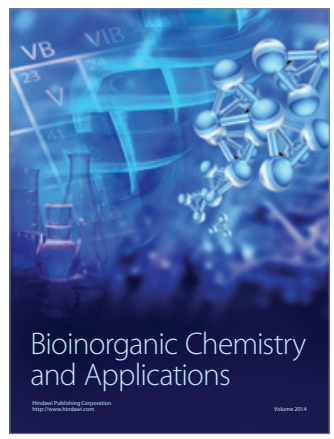

Inorganic Chemistry
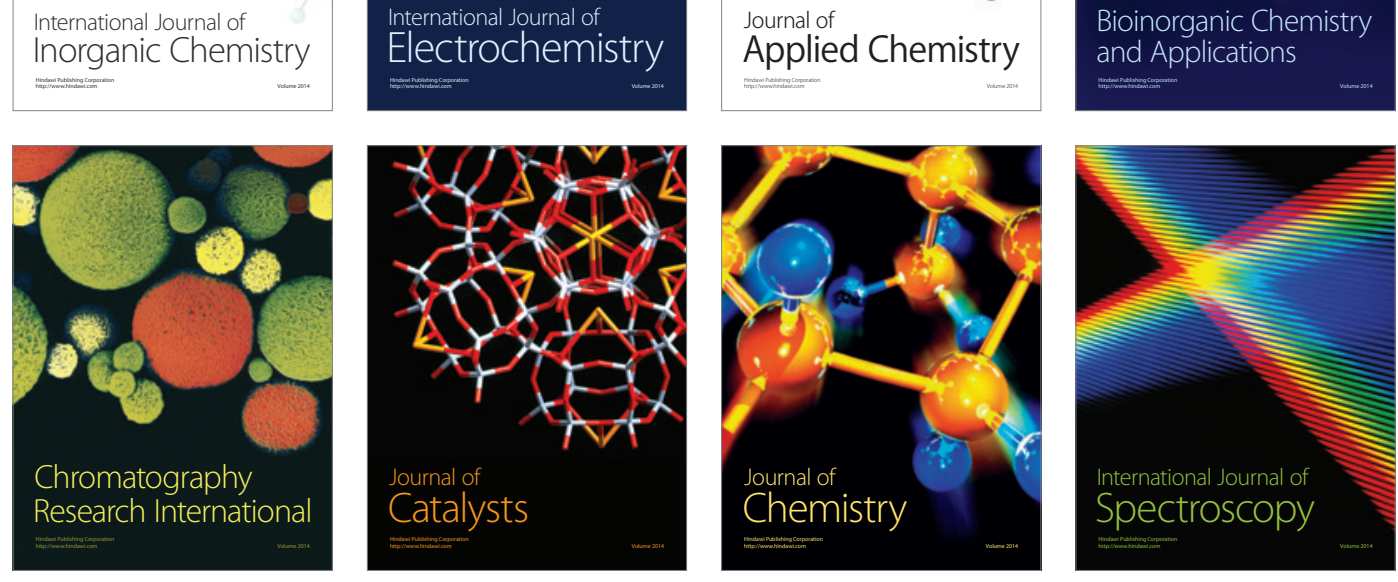